\title{
Karayolu Peyzajı ve Manzara Yolları
}

\author{
Işık SEZEN* \\ Atatürk Üniversitesi, Mimarlık ve Tasarım Fakültesi, Peyzaj Mimarlığı Bölümü, 25240, Erzurum, Türkiye.
}

*e-mail: isiksezen@atauni.edu.tr.

Öz

Insanların uzun süren karayolu ile yaptıkları yolculuklarının daha zevkli, daha huzur verici geçmesi, karayolu çevresindeki manzaranın görsel kalitesinin yüksek olmasına bağılılı. Karayolu çevresi manzarasını; peyzaj karakteri, arazi şekli, bitki örtüsü, su varlığı ve kültürel özellikler önemli derecede etkilemektedir.

Bir karayolunun manzara yolu değerine sahip olabilmesi için; karayolu boyunca yolcuları etkileyen sürprizler olmalıdır. Çeşitli jeolojik oluşumlara, kayalık alanlar ve uçurumlara, topoğrafyadaki ani değişimlere, geniş ovalara, kanyonlara, kayalar arasından aşağıya doğru akan doğal şelalelere, renk etkisine sahip bitki örtüsüne, kasvetli ormanlık alanlara, ayna etkisi yapan geniş su yüzeylerine, kırsal peyzaj manzaralarına, yol kıvrımlarına eşlik eden dereler ve diğer ilgi çekici doğal güzelliklere rastlanmalıdır.

Bu çalışmada; karayolu peyzajı, manzara yolları, manzara yollarının planlama ilkeleri, karayolu peyzajı ve manzara yolları üzerine yapılmış ulusal, uluslararası araştırmalar, başta Amerika Birleşik Devletleri olmak üzere dünyadaki önemli manzara yolları ele alınarak karayolu peyzajı ve manzara yollarının önemi vurgulanmıştır.

Anahtar Kelimeler: Karayolu, peyzaj, karayolu peyzajı, manzara yolları

\section{Highway Landscape and Scenic Roads}

\begin{abstract}
The fact that people spend more enjoyable and long time in travelling on highways depends on the degree of visual quality of the scenery around the highway. Landscape characteristics, landforms, vegetation, water surface and cultural characteristics affect the scenery around highway.

In order for a highway to carry the features of a scenic route, it should offer surprises that affect passengers along it. It should be accompanied by various geological formations, rocky areas and cliffs, sudden changes in the topography, wide plains, canyons, natural waterfalls flowing down the rocks, vegetation cover with color effect, dreary forest zones, water surfaces with mirror effects, rural landscapes and surface runoffs in convenience with road curves and other interesting natural beauties.
\end{abstract}

The importance of highway landscape and scenic roads was emphasized in the present study by taking into consideration the important scenic roads in the world, especially the United States, national and international researches on highway landscapes and scenic roads and their planning principles.

Keywords: Highway, landscape, highway landscape, scenic roads

\section{Giriş}

Karayolu peyzajının değerlendirilmesinde, karayolu çevresindeki bitki örtüsü, tarihi değerler, arazi kullanımı, sosyal-ekonomik yapı, sürücü ve yolculara ilginç ve keyifli bir yolculuğa imkân verme,

Atıf: Sezen, I. (2018). Karayolu Peyzajı ve Manzara Yolları. Mimarlık Bilimleri ve Uygulamaları Dergisi (MBUD), 3 (1), 54-65. DOI: $10.30785 / \mathrm{mbud} .356523$ 
arazide ilginç odak noktaların varlığı, arazide kötü görüntüye sahip yerlerin gizlenmiş olması, yol ile etrafındaki manzaranın uyumu önemlidir (Özgünç, 1999). Yol çevre düzenleme çalışmaları ulaşım hizmetleri ile paralel olarak gelişmiştir. M.Ö. 1000 yıllarında Çinliler, Romalılar ve Yunanlılar yol boylarında konaklama tesisleri kurmuşlardır. Buralarda yolcuların dinlenme, konaklama ve yemeiçme ihtiyaçları karşılanmıştır.

18. yüzyılın başlarında, Fransız krallığında önemli derecede söz sahibi olan Karayolu Mühendisi Gautier, yolu çok fazla gölgelendirdiğinden ve yolun çabuk kurumasına engel olduğundan yol kenarında bulunan ağaç ve çalı formlarının kesilmesini uygun bulmuştur.

Rönesans devri ve özellikle Fransız Barok stilinde ise, buna tamamen karşıt bir anlayış ve uygulama hakimdir. Barok üslubuna uygun radyal yollar beş sıralı ağaçları ile şehirleri kat edip kırsal kesimlere ulaşmıştır. "Alle" olarak adlandırılan, iki tarafı düzgün sıralı yollar, bu devir ve adı geçen üslup ile başlamıştır (Selimoğlu, 1994; Ertekin ve Çorbacı, 2010).

19. asır Avrupa'sında yol ağacı manzarayı güzelleştirmeyi ve toza engel olmayı amaçlıyordu. Bu amaç için uzun süre meyve ağaçlarından yararlanılmıştır (Koç 1979; Ertekin ve Çorbacı, 2010). 1920-1930 yıllarında karayollarında erozyon kontrolü başlamıştır (Sosyaler, 1973; Ertekin ve Çorbacı 2010).

Karayolunun geçtiği kırsal alan devamlı değişmektedir. Bundan dolayı hiç değişmeyen çizgisel karayolu ile devamlı değişen peyzaj arasındaki çelişkili durum bağdaştırılmalıdır. Bu işlem, güzergâh boyunca karayolu çevresinin peyzaj açısından uygun bir şekilde düzenlenmesi ile sağlanabilir.

Amerika'da rekreasyonel hareketin çoğunluğu bugün artık büyük mesafelere ulaşmaya yönelmiştir. Ülkemizde de bu mesafelerin günümüzde arttığı ve kısa tatillerde bile araçlarla güney tatil yerlerine gidilip gelindiği gözlenmektedir. Bu kısa tatil sürelerinin büyük bir çoğunluğunun yollarda geçtiği düşünülürse, iç ve dış turizm de dikkate alındığında; ulaşım sistemimizin rahat, ilginç doğal peyzajlar sunan emniyetli bir güzergâhtan geçmesi, karayollarındaki yolculukları teşvik edici hale getirmektedir (Ürgenç, 2000; Öztürk, 2002).

Manzara yolları ticari ulaşıma açık olmakla birlikte, ana amacı rekreasyon olan, doğal ve kültürel yönden yüksek potansiyele sahip alanlar ve piknik alanları, kampingler, atlı bisikletli gezinti yolları, sportif alanlar gibi rekreasonel kullanımlara yer verilen yollar olarak tanımlanmaktadır.

Manzara yolu, çarpıcı manzara değerlerine sahip bir arazide planlanan veya inşa edilen emniyetli, estetik olarak çekici ve trafiği sınırlı bir yoldur. Manzara yolları, büyük ölçüde dinlenme amaçlı trafiği ve çok az miktarda ticari ya da transit trafiği cezbeden, çoğunlukla bir ya da iki şeritli yol olup, arazi durumuna, trafiğin tip ve hacmine ve tasarım hızına bağlı olarak farklı standartlarda yapılmaktadır (Seçkin, 1985; Seçkin, 1997).

Manzara yolları; ana manzara yolları ve tali manzara yolları olmak üzere ikiye ayrılır. Ana manzara yolları, genellikle iki şeritli 55-65 km/h dizayn hızına sahip, yüksek estetik ve kültürel değere sahip, seyahat süresi 2-4 saat olan yollardır. Tali manzara yolları, bir veya iki şeritli, 30-50 km/h dizayn hızına sahip, gözden uzak manzaralara giden veya ana yoldan ayrılan, seyahat süresi 1 saat olan arka yollardır. Tali manzara yolları, ana yollarla bağlantılı olmalıdır (Seçkin, 1985).

Little (1995)'a göre manzara yolları, genellikle bir yol ya da otoyol/karayolu boyunca devam eden ve belli yerlerde yayaların aktivitelerine de olanak sağlayan noktaların bulunduğu, otomobillerden inilerek yer yer bu olanaklardan yararlanılan mekânlardır (Arslan ve ark., 2007).

Manzara yollarının planlama ilkeleri ilgili literatürde aşağıdaki şekilde ele alınmıştır:

- Geleceğe ait kullanım tahminlerine dayanan tasarım hacimleri ve kıyaslamayı mümkün kılan mevcut yollar üzerindeki aylık, günlük ve saatlik yüksek trafik hacim etütleri,

- Manzara yolu ve çevresinin; bakış yeri, vista ve benzeri yol kenarı olanaklarının yaklaşık optimum kapasiteleri,

- Planlanan manzara aktivitesinin tipi (Seyahat edenlerin manzara seyri, özel olarak yapılan manzara gezintisi, içgüdüsel amaçsız gezinti),

- Illgili, yaş, cinsiyet vs. itibariyle beklenen turistlerin özellikleri, 
- Güzergâhın manzara, kültürel veya tarihsel niteliği,

- Mevcut aktivitelerin değişimi,

- Ana yoldan ulaşılabilirliği,

- Ana ziyaretçilerin nüfusu ve yaşadığı yerler,

- Diğer alanlar ve trafik istekleri ile tasarlanan manzara yolunun uygunluğu,

- Güzergâhla tasarım ve emniyet özelliklerinin uyumu,

- Bölgesel nüfusun eğilimleri ve projenin milli önemi,

- Gelecekte kullanılacak araçların büyüklük ve özellikleri,

- Ziyaretçilerin kullanacakları araçların seyahat hızları esnasında yakalayacakları peyzaj firsatları,

- 20 yıllık bir planlama dilimindeki fayda ve masraf durumu tespit edilmelidir (Seçkin, 1985).

Dünya'da ise karayolu peyzaj planlama çalışmaları ile ilgili ilk örnekler; 1930 'larda başlamıştır. Bu tarihlerde karayollarında meydana gelen erozyonu önlemek için peyzaj mimarları ve orman mühendisleri bağ kütükleri ve ağaççıkların kullanılması olanaklarını incelemişlerdir (Sosyaler, 1973; Çorbacı ve Var, 2011).

Ülkemizde yapılan karayolu peyzaj planlama ile ilgili ilk çalışma; Saatçioğlu'nun (1960), yol kenarı ağaçlarının silvikültürel ve estetik özelliklerini incelediği çalışmadır. Daha sonra Akdoğan (1967), Ankara-istanbul karayolu peyzaj planlamasının özelliklerini ve ilkelerini saptamıştır (Çorbacı ve Var, 2011). Tanrıverdi (1975)'nin de karayolu ağaçlandırmaları üzerine bir çalışması bulunmaktadır.

Illk geniş kapsamlı peyzaj uygulama projesi Pamay ve arkadaşları tarafından Boğaz İçi Çevre Yolları́nın bazı kesimleri için yapılmıştır (Bayraktar, 1980; Çorbacı ve Var, 2011).

Acar (1993)'ın Trabzon-Rize arası karayolu ve yakın çevresinin doğal, sosyo-kültürel ve görsel değerlerinin peyzaj gelişimindeki rolü ve peyzaj planlama açısından incelenmesi üzerine yaptığı araştırmada; karayolu ve yakın çevresinde planlı bir peyzaj gelişimi sağlayabilmek için yolun "manzara yolu" olarak değerlendirme olanaklarını araştırmıştır. Altunal (1998) ise, karayolları ağaçlandırma çalışmalarının kritiği yapmış, karayolları ağaçlandırmasında tür seçiminin üzerinde durmuştur (Çorbacı ve Var, 2011).

Karayolu peyzajı ve manzara yolları üzerine yapılan ulusal ve uluslararası bazı çalışmalar Tablo 1'de derilmiştir gösterilmiştir.

Tablo 1. Karayolu peyzajı ve manzara yolları üzerine yapılan ulusal ve uluslararası bazı literatürler

\begin{tabular}{|c|c|}
\hline Literatürler & Araştırmacılar \\
\hline Scenic and recreational highway study for the state of Washington & Jones etal., 1976 \\
\hline Trabzon-Erzurum Karayolunun Rekreasyon ve Turizm Yönünden Planlama İlkelerinin Saptanması & Güçlü, 1982 \\
\hline Peyzaj Yolu Kavramı Ve Dizayn Esasları. İstanbul Üniversitesi Orman Fakültesi & Seçkin, 1985 \\
\hline Karayolu ve Peyzajı. İstanbul Üniversitesi Orman Fakültesi Dergisi, B(36,4): 46-53. & Seçkin, 1986 \\
\hline Commercial higway landscape reclamation: Aparticipatory approach & $\begin{array}{l}\text { Lambe and Smardon, } \\
1986\end{array}$ \\
\hline $\begin{array}{l}\text { Adana-Imamoğlu-Kozan Yeni Devlet } \quad \text { Karayolunun } \\
\text { Değerlendirilmesi Üzerine Bir Araştırma }\end{array}$ & Tabrizi, 1988 \\
\hline $\begin{array}{l}\text { Tarsus-Pozantı Ayrımı-Adana-Gaziantep Otoyolu ( Km } 44+600-K m 125+000) \text { arası yapılan peyzaj } \\
\text { planlama çalışmaları üzerine bir araştırma. }\end{array}$ & Avşar, 1993 \\
\hline Determining scenic quality along highways: a cognitive approach & Kent, 1993 \\
\hline $\begin{array}{l}\text { Scenic Routes Linking And Protecting Natural And } \\
\text { Cultural Landscape Features: A Greenway Skeleton }\end{array}$ & Kent and Elliott,1995 \\
\hline Kent Girişi Karayolu Koridorunun Mekânsal Değerlendirmesine Yönelik Bir Araştırma & Çil, 1995 \\
\hline
\end{tabular}




\begin{tabular}{|c|c|}
\hline Bartın-İnkumu Karayolunun ve İnkumu’nun Peyzaj Değerleri Açısından İncelenmesi & Ertaş, 1998 \\
\hline Tem-hadımköy-kınalı Arası Peyzaj Planlaması Üzerinde Görsel Araştırmalar & Özgünç, 1999 \\
\hline Kent içi ve kent dışı karayolu ulaşım sisteminde bitkilendirmenin trafik tekniği yönünden işlevleri & Öztürk, 2002 \\
\hline Importance of scenic byways in route choice: a survey of driving tourists in the United States & Eby and Molnar, 2002 \\
\hline A method for assesing highway qualities to integrate values in highway planing & Brown, 2003 \\
\hline Erzurum-Rize Karayolu Koridorunun Görsel Kalite Analizi & Karahan ve Yılmaz, 2004 \\
\hline Assessing the validity and reliability of descriptor variables used in scenic highway analysis & Clay and Smidt, 2004 \\
\hline Gümüşhane-Trabzon Karayolu Güzergâhı Peyzaj Değerlerinin İrdelenmesi & Koçan, 2007 \\
\hline Bartın-Amasra Karayolu Güzergâhının Doğal Peyzaj Özellikleri Üzerindeki Etkilerinin Saptanması & Tunay vd., 2008 \\
\hline Isparta-Eğirdir Karayolunun Peyzaj Planlama İlkeleri Açısından İncelenmesi & $\begin{array}{l}\text { Dağıstanlıoğlu ve Önder, } \\
2009\end{array}$ \\
\hline Karayollarında Peyzaj Planlama Ve Bitkilendirme Çalışmaları & Ertekin ve Çorbacı, 2010 \\
\hline Visual assesment for the eveluation of Erzurum-Bayburt-Of Higways as scenic road & Sezen and Yılmaz, 2010 \\
\hline $\begin{array}{l}\text { Antalya-Alanya devlet karayolundan kaynaklanan (I. kesim) çevresel etkilerin peyzaj mimarlı̆̆ı } \\
\text { açısından değerlendirilmesi }\end{array}$ & $\begin{array}{l}\text { Kınıklı ve Mansuroğlu, } \\
2010\end{array}$ \\
\hline $\begin{array}{l}\text { Bartın-Amasra Karayolunun Peyzaj Özelliklerinin Peyzaj Planlama Açısından İrdelenmesi Ve } \\
\text { Sorunların Giderilmesine Çeşitli Öneriler }\end{array}$ & Çorbacı ve Var, 2011 \\
\hline The long and winding roads: Perceived quality of scenic tourism routes & $\begin{array}{l}\text { Denstadli and Jacobsen, } \\
2011\end{array}$ \\
\hline Landscape design of mountain highway tunnel portals in China & Fei etal., 2012 \\
\hline User's Preferences of Highway Landscapes in Malaysia: A Review and Analysis of the Literature & Jaal and Abdullah, 2012 \\
\hline $\begin{array}{l}\text { Assessing highway's impacts on landscape patterns and ecosystem services: A case study in Puli } \\
\text { Township, Taiwan }\end{array}$ & Wu etal., 2014 \\
\hline Bingöl-Erzurum Karayolu Güzergâhının Görsel Kalite Analizi & Caf, 2014 \\
\hline Analyzing how travelers choose scenic routes using route choice models & Alivanda etal., 2015 \\
\hline Ekolojik Koridorların Turizme Katkısı: Erzurum-Bayburt-Of Karayolu Güzergahı & Sezen ve Yılmaz, 2017 \\
\hline
\end{tabular}

Manzara yolu olarak adlandırılan birçoğu aynı zamanda macera yolu niteliğinde olan ve en tehlikeli yollar listesinde de yer alabilen Amerika'daki önemli manzara yolları Şekil 1'de gösterilmiştir. URL-1, 2, 3, 4 (2017).

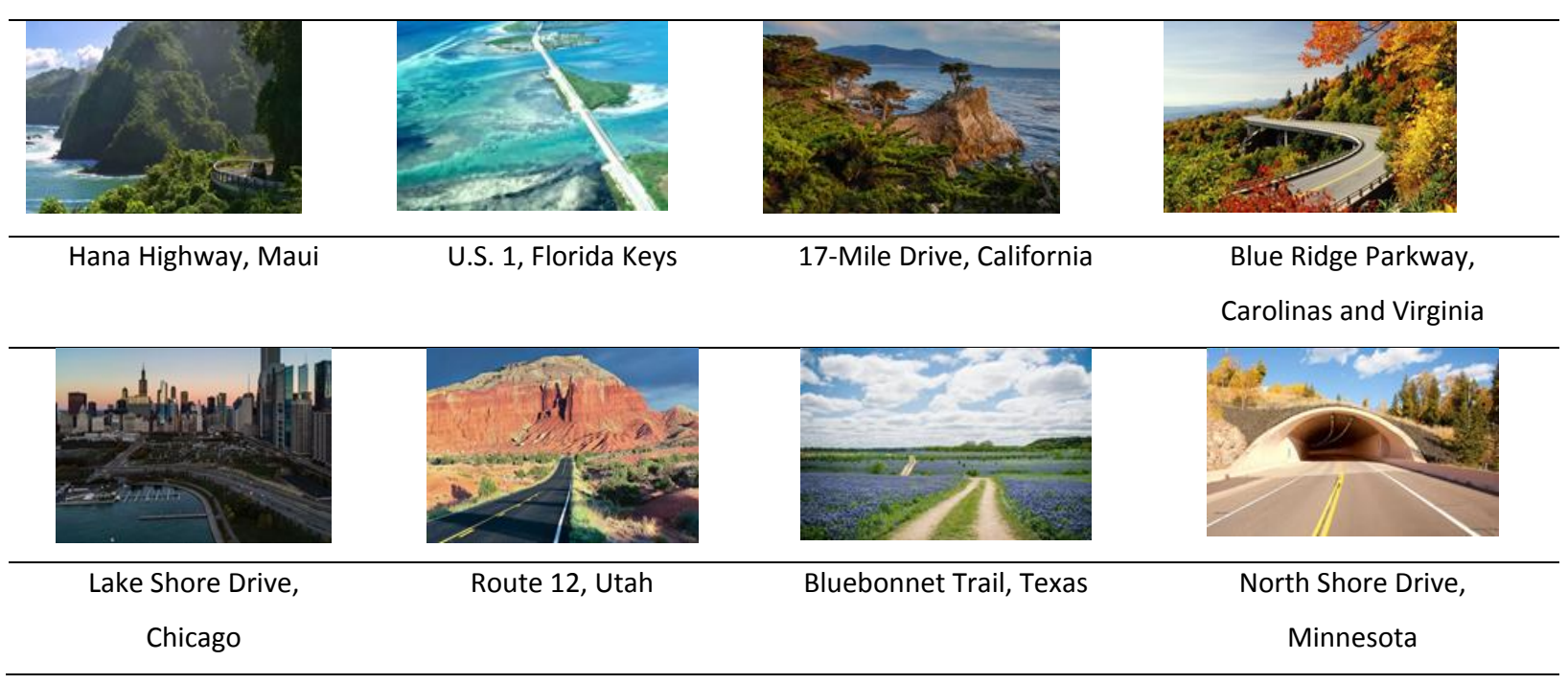




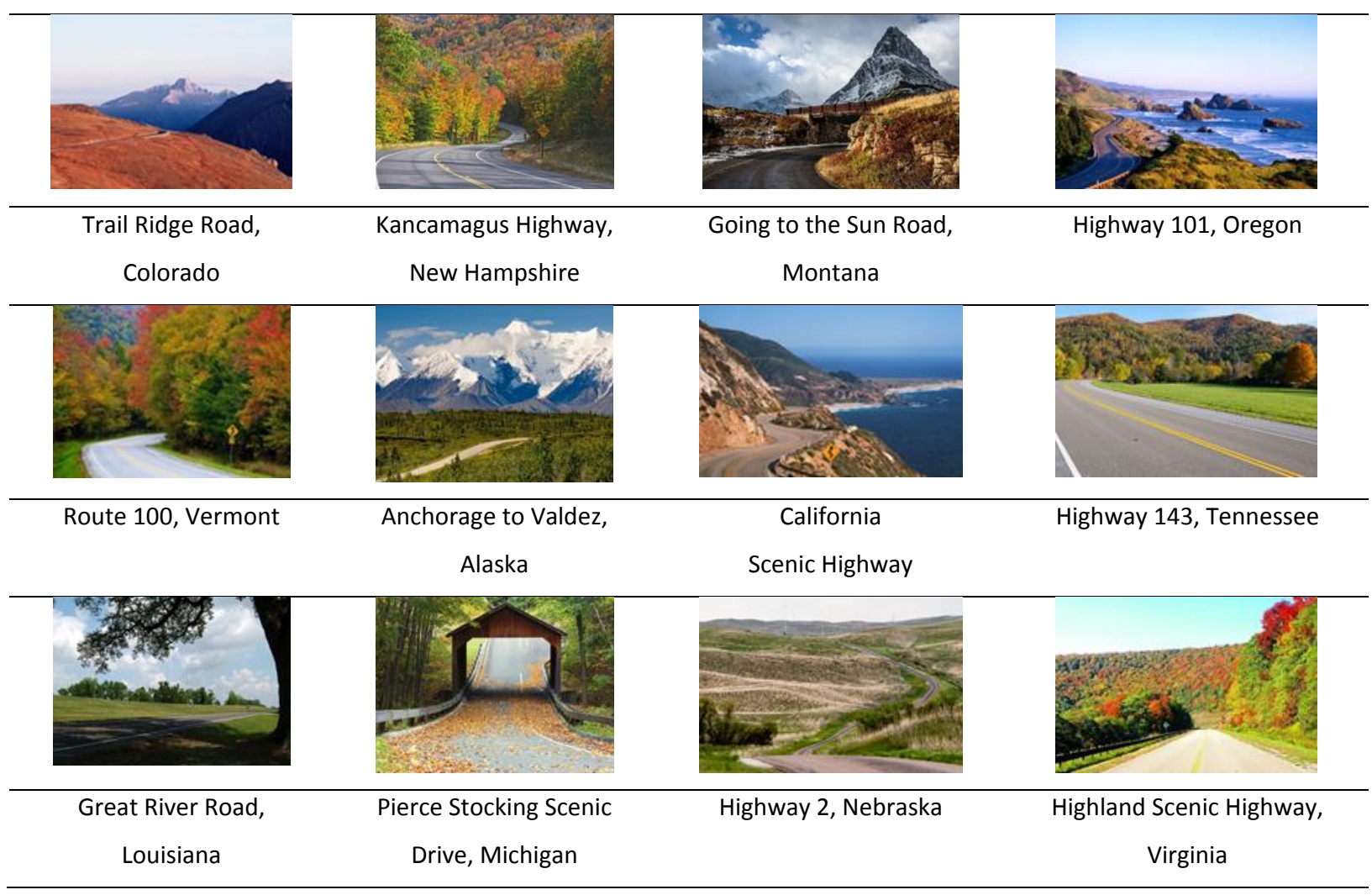

Şekil 1. Amerika'daki önemli manzara yolları

Dünya'nın en ilgi çekici bazı manzara yolları URL-5,6 (2017) da Şekil 2'de gösterilmiştir.

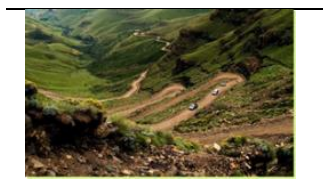

Sani Geçidi: Güney Afrika ile Lesotho arasında bulunmaktadır. Tehlikeli geçitten ancak $4 \times 4$ araçlar ile geçilebilmektedir.

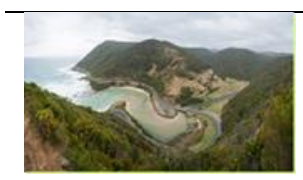

Büyük Okyanus Yolu: Avustralya'dadır. Müthiş bir Okyanus manzarasına sahip bu yol 1. Dünya Savaşı'nda ölenlere adanmıştır.

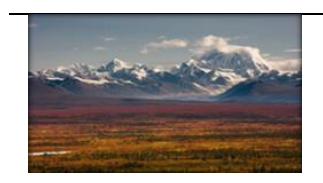

Denali Yolu: Alaska'dır. Çoğunlukla çakıl taşı ile kaplı bu yol ziyaretçilerini Alaska vahşi doğasının derinliklerine taşımaktadır.

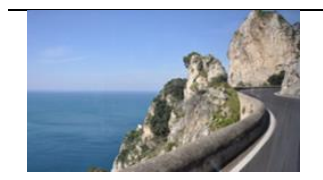

Amalfi Sahili: İtalya'dadır. Çok etkileyici görsel zenginlikler sunan Amalfi Sahili, Akdeniz manzarası içeren birçok farklı rotaya sahiptir.

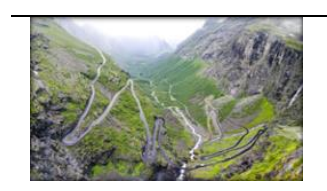

Trollstigen: Norveç'tedir. Çok keskin ve dar virajlara sahiptir.

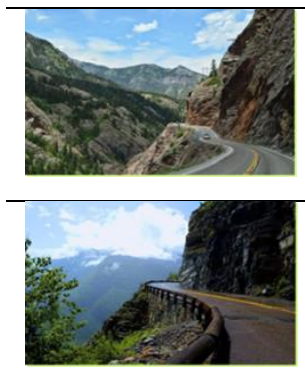

Million Dollar Yolu: ABD’nin Colorado eyaletindedir. Dar geçitleri, keskin dönüşleri, uçurumları ile $A B D^{\prime}$ nin en popüler uzun yollarındandır.

Going-to-the-Sun Road (Güneşe giden yol): ABD’nin Montana eyaletinde Glacier National Park'ta yer almaktadır. Buzul gölleri ve tundra bitki örtüsü içinden geçmektedir. 


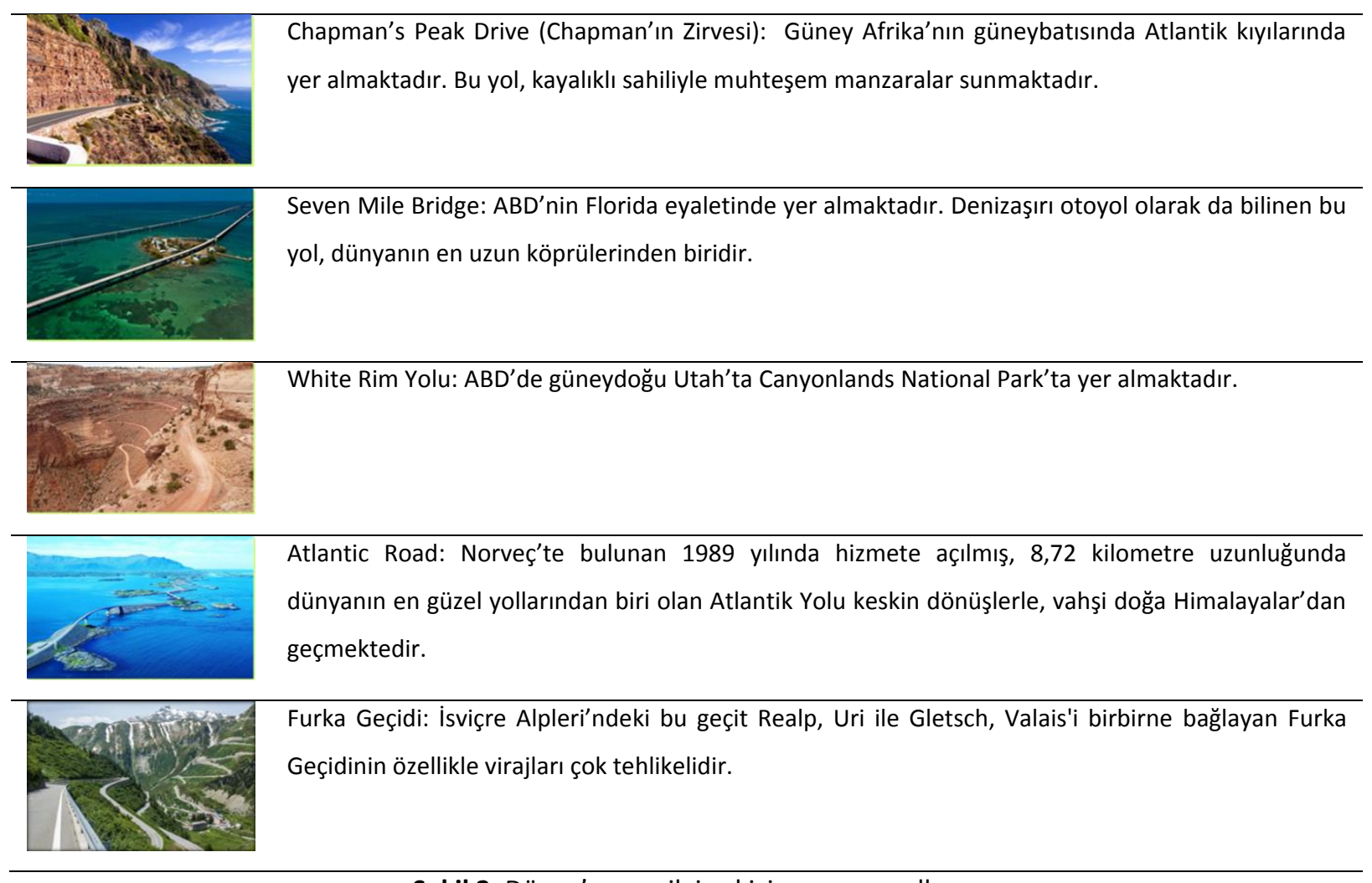

Şekil 2. Dünya'nın en ilgi çekici manzara yolları

Dünyada ölüm yolları olarak bilinen ulaşımı çok tehlikeli olan çok sayıda karayolu URL-7 (2017) bulunmaktadır. 2015 yılı içerisinde Türkiye'den Bayburt-Of yolu da bu yollar arasında anılmaya başlamıştır. Bu yollar macera tutkunları tarafından tercih edilmektedir. Çoğu aynı zamanda muhteşem bir manzaraya sahiptir. Şekil 3'te bu yollardan önemlilerine yer verilmiştir.

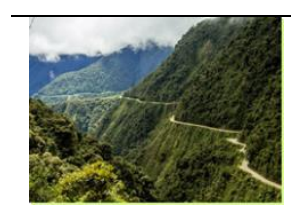

Kuzey Yungas Yolu: Ölüm Yolu olarak bilinen Kuzey Yungas Yolu 61-69 km uzunluğunda, Bolivya’nın başkentinden Amazon bölgesine uzanmaktadır.

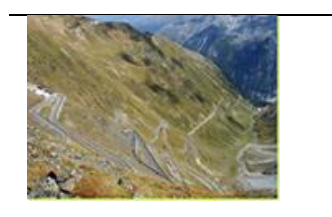

italya Stelvio Geçit Yolu: Doğu Alp’lerinin yüksek noktalarından kıvrılan ve bölgedeki en yüksekteki yol dünyanın en tehlikeli yolları arasında gösterilmektedir.

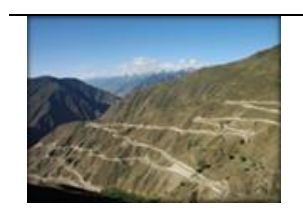

Tibet Sichuan Karayolu: Sürekli meydana gelen toprak kaymaları ile meşhur ve dünyada en çok ölümlü kazanın da meydana geldiği yol olarak biliniyor.

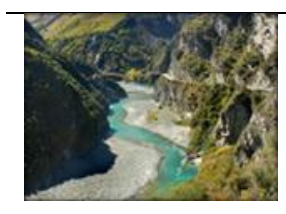

Yeni Zelanda Skippers Kanyon Yolu: Çok dar ve tehlikelerle dolu bir yoldur. Vahşi doğa içinde sonsuza uzanma hissi vermektedir.

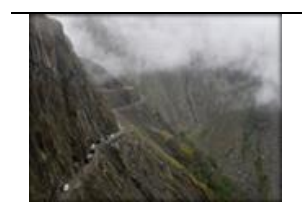

Hindistan Zoji Geçit Yolu: Batı Himalayalar'ın en tehlikeli yollarından biridir. Özellikle ağır kış şartlarında kullanımında büyük tehlike yaratan yoldur. 


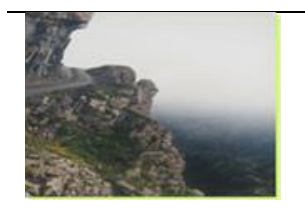

Bayburt-Of Yolu, Turkey: 2015 yılı içinde yapılan bir araştırmaya göre dünyanın en heyecan verici yolları arasına Bayburt-Of yolu da eklenmiştir.

Şekil 3. Dünyadaki manzara değeri de olan ölüm yolları

Türkiye'nin en güzel manzaralı karayolu güzergâhları URL-8 (2017) Şekil 4'de verilmiştir.

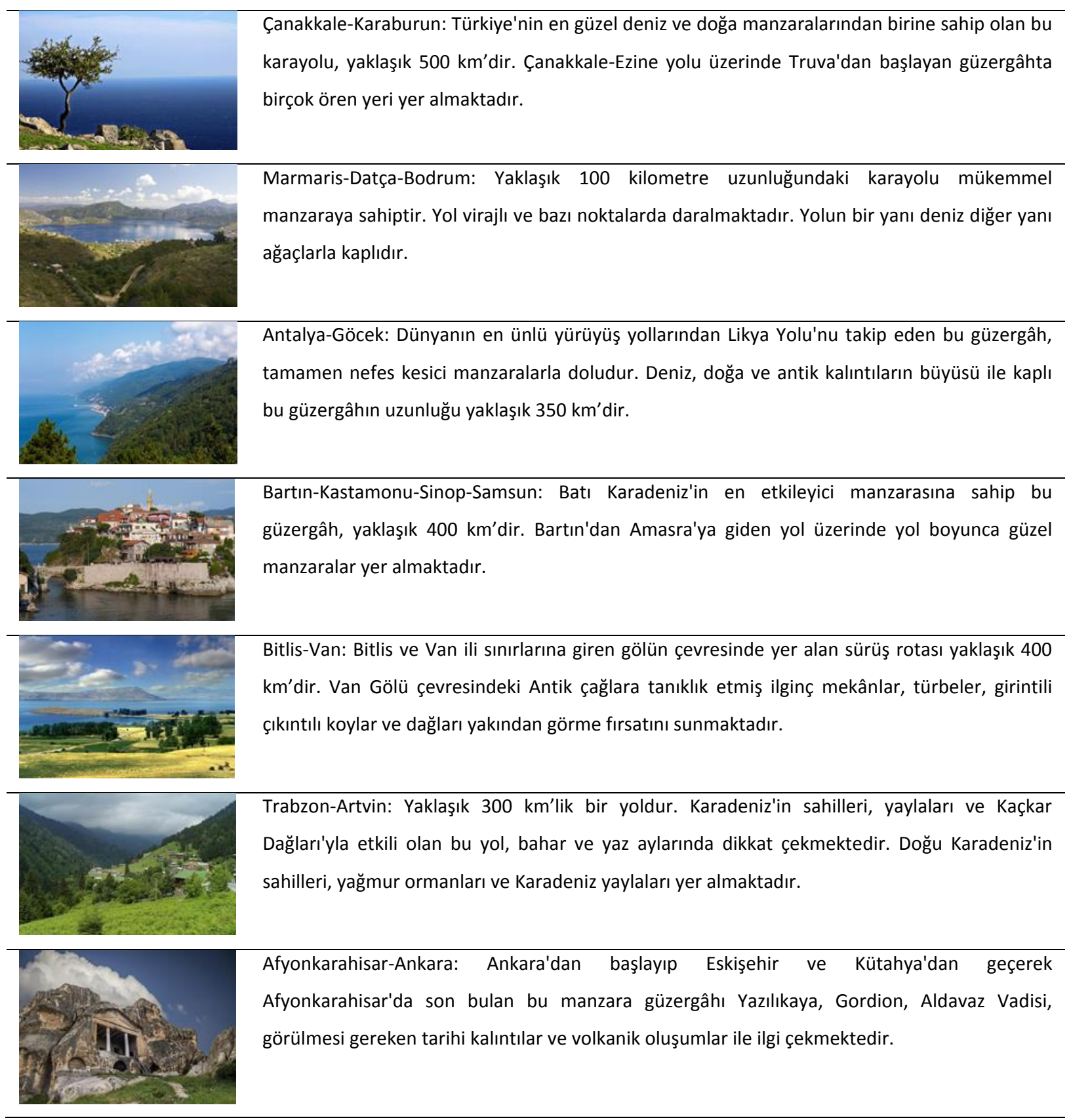

Şekil 4. Türkiye'nin en güzel manzaralı karayolu güzergâhları

\section{Sonuç}

İnsanların dünyayı kendi kullanış biçimleri ve yaşam şekillerine uygun biçime getirme çabaları bağlamında, doğa üzerinde en fazla etkili olan mühendislik yapıları karayollarıdır. Dünya üzerinde adeta bir ağ oluşturan karayolları, içlerinden geçtikleri peyzajı ikiye bölen planlama elemanları oldukları kadar, peyzajla bütünleşen elemanlar da olmalıdırlar. Kentsel yaşamın değişen koşullarıyla birlikte, özellikle son altmış yıllık süre içerisinde otomobil sahipliğinin artması ve yol tekniğindeki gelişmeler mobilitenin de artmasına yol açmıştır (Öztürk, 2002). 
Dünya'daki manzara kalitesi ile dikkat çeken önemli karayolları incelendiğinde Sezen (2015)'in de belirttiği gibi karayolu çevresindeki peyzajın görsel kalitesinin yüksek olmasını etkileyen faktörler aşağıda belirtildiği gibidir.

Karayolu güzergâhı boyunca sürekli olmasa bile deniz, nehir, çay, dere, baraj, göl gibi su varlığı bulunuyorsa, manzaranın görsel kalitesi artmaktadır (Şekil 5).

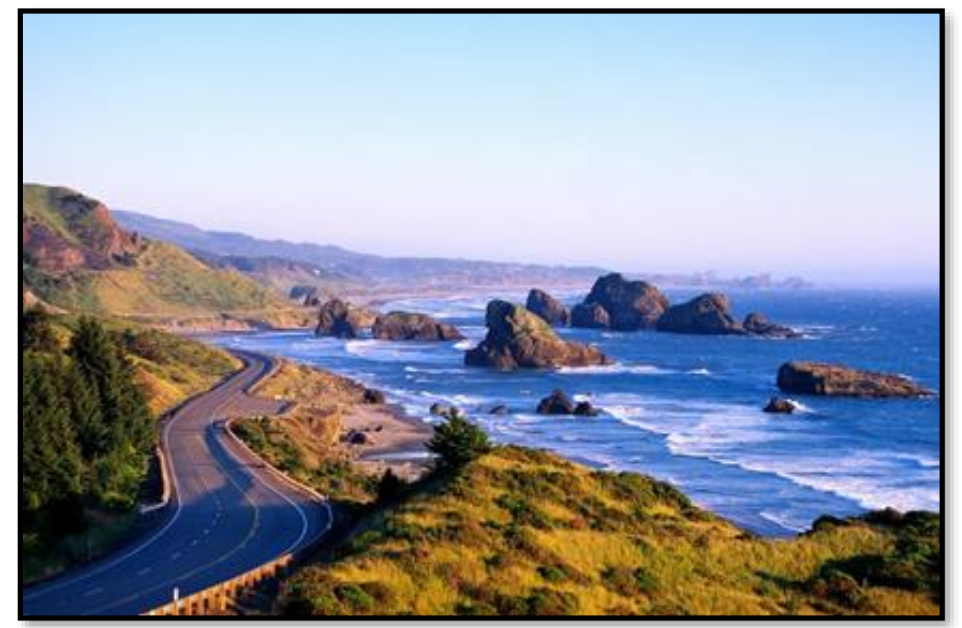

Şekil 5. Karayolu çevresinde su manzarası, Highway 101, Oregon, URL-1 (2017).

Karayolu güzergâhı boyunca doğal bitki örtüsünün zenginliği, ilkbahar ve sonbahardaki renk etkisi manzaranın görsel kalitesini artırmaktadır (Şekil 6).

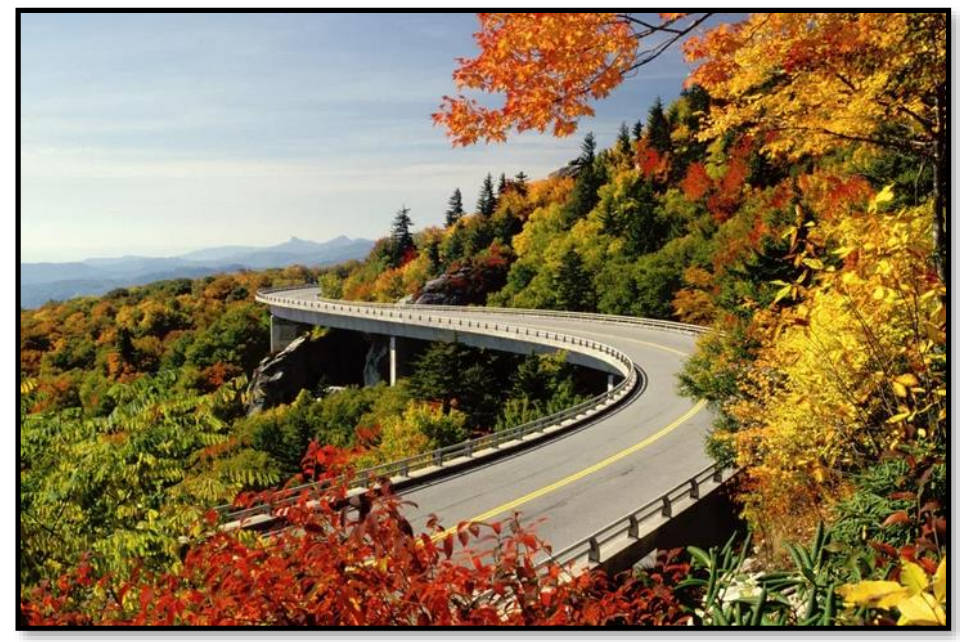

Şekil 6. Karayolu güzergâhı boyunca doğal bitki örtüsünün zenginliği, Blue Ridge Parkway, Carolinas and Virginia (Foto: Andre Jenny), URL-1(2017).

Dağlar arasından kıvrılarak geçen karayolu güzergâhları monotonluktan uzak ve heyecan vericidir. Bu kıvrımlar doğal bir su varlığı ve bitki örtüsü ile birlikte çok daha yüksek bir manzara görsel kalitesi sunmaktadır (Şekil 7). 


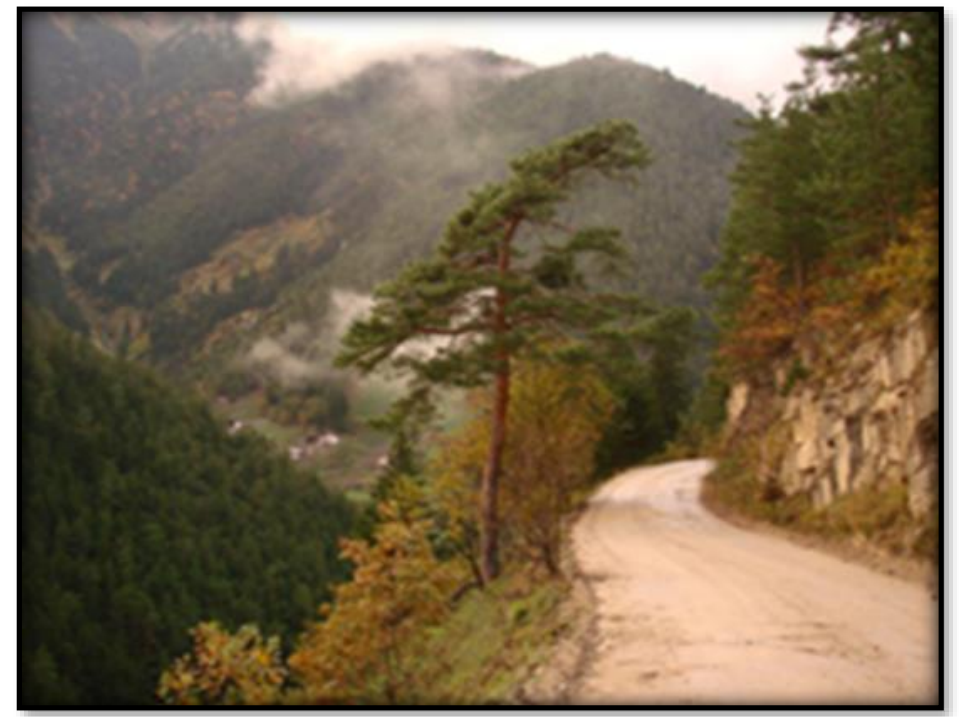

Şekil 7. Dağlar arasından kıvrılarak geçen karayolu, Bayburt-Of Karayolu, Türkiye (Orijinal)

- Karayolu, kırsal peyzaj içinden geçiyorsa, kırsal peyzaj içinde yer alan tüm öğelerin doğal ve çevreyle uyumlu olması karayolu çevresindeki manzaranın görsel kalitesini yükseltir.

- Karayolu çevresinde yer alan insan yapımı kültürel elemanlar doğayla uyumlu olmalıdır. Örneğin karayolu çevresinde köy, yayla gibi bir yerleşim alanı mevcutsa, doğal malzemelerle yapılmış binalar arasında modern binaların yer alması görsel kaliteyi zayıflatmaktadır.

- Karayolu güzergâhı boyunca devam eden tüm doğal ve kültürel elemanlar arasında bir uyum (harmoni) bulunuyorsa manzaranın görsel kalitesi daha yüksektir.

- Renkler arasında geçiş, renk çeşitliliği karayolu çevresi manzarasının görsel kalitesi etkileyen önemli faktörlerden birisidir. Renklerin bu etkileri bitki örtüsünün çeşitliliği ve çiçeklenme dönemi, varsa meyveli dönemi gibi mevsimsel değişimi, özellikle ilkbahar ve sonbaharda bitkilerin renklerindeki değişim; göl, nehir, dere, çay, baraj gölü gibi su yüzeylerinin varlığı ve diğer doğal ve kültürel elemanlar ile sağlanmaktadır.

- Karayolu çevresindeki manzarayı oluşturan elemanların doğal ve değişime uğramamış olmaları görsel kaliteyi olumlu etkilemektedir.

- Bir karayolu manzarası monoton olmamalıdır. Sürekli orman içinden veya kesintisiz dere, nehir, göl kenarından geçen bir karayolunda seyahat etmek insanlar için sıkıcı olabilir. Karayolu boyunca manzarada çeşitlilik, farklııık olmalıdır. Su yüzeyleri, ormanlık alanlar, dağlık kayalık alanlar, kırsal peyzaj manzaraları ve diğer doğal ve kültürel yapılar belirli aralıklarla, bir ahenk içinde tekrar edildiğinde görsel kalite daha etkileyici olmaktadır (Sezen, 2015).

- Karayolu güzergâhı boyunca yolcuları büyüleyen ilginç sürprizler olmalıdır. Çeşitli jeolojik oluşumlar, kayalık alanlar ve uçurumlar, topoğrafyadaki ani değişimler, geniş ovalar, kanyonlar, kayalar arasından aşağıya doğru akan doğal şelaleler, renk etkisine sahip bitki örtüsü, kasvetli ormanlık alanlar, ayna etkisi yapan geniş su yüzeyleri, kırsal peyzaj manzaraları, yol kıvrımlarına eşlik eden dereler ve diğer ilginç doğal güzelliklerle her an karşılaşma ihtimali olan yolcular zevkli bir yolculuk yapmaktadırlar (Sezen, 2015)

- Karayolu çevrecindeki çeşitli jeolojik oluşumlar, kayalık alanlar ve uçurumlar, doğal şelaleler (Şekil 8) manzaraya çeşitlilik sağlar. 

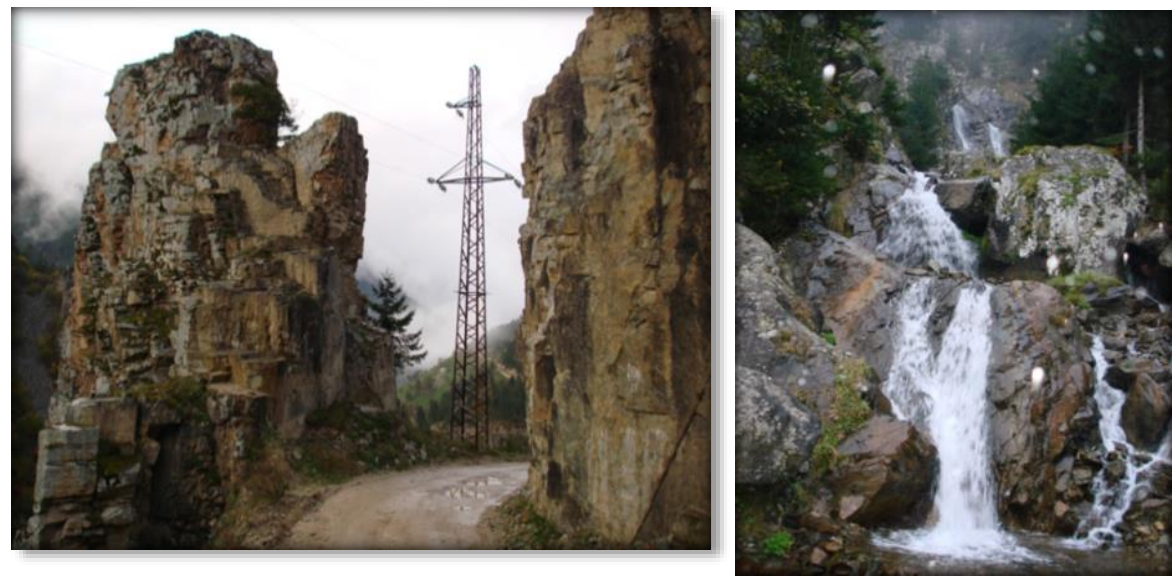

Şekil 8. Karayolu çevrecindeki çeşitli jeolojik oluşumlar, kayalık alanlar ve uçurumlar, doğal şelaleler, Bayburt-Of Karayolu, Türkiye (Orijinal)

Türkiye'de Bayburt-Trabzon arasında yer alan Bayburt-Of karayolu 2015 yılı içinde dünyanın en tehlikeli yolları arasına girmiştir. Bayburt-Of karayolu aynı zamanda sahip olduğu doğal özellikleri ile manzara kalitesi ile de çok dikkat çekmektedir. Bayburt-Of karayolunun manzara yolu olarak değerlendirilmesi Sezen (2009) tarafından da önerilmiştir.

Başta $A B D$ olmak üzere tüm dünya örneklerinde görüldüğü gibi manzara niteliğe sahip olan karayollarının birçoğu macera yolu niteliğindedir. Bu yolların tehlikeli, heyecan verici olma özellikleri ilginç doğal özelliklere sahip olmasından kaynaklanmaktadır. ilginç doğal özellikler de yolların manzara kalitesini artırmaktadır. Ve bu yolların manzara yolu olarak değerlendirilmesine olanak sağlamaktadır.

\section{Kaynaklar}

Aca,r C. (1993). Trabzon-Rize Arası Karayolu ve Yakın Çevresinin Doğal, Sosyo-Kültürel ve Görsel Değerlerinin Peyzaj Gelişimindeki Rolü ve Peyzaj Planlama Açısından İncelenmesi. Karadeniz Teknik Üniversitesi Fen Bilimleri Enstitüsü Peyzaj Mimarlığı Anabilim Dalı Yüksek Lisans Tezi, Trabzon, 134 s.

Akdoğan, G. (1967). Ankara-İstanbul Karayolu Güzergâhının Peyzaj Özeliklerinin Etüdü ile Peyzaj Planlaması Yönünden Ele Alınması Gereken Problemler. Karayolları Genel Müdürlüğü Yayınları No: 158, Ankara.

Alivanda, M., Hochmaira, H. and Srinivasanb, S. (2015). Analyzing how travelers choose scenic routes using route choice models. Computers, Environment and Urban Systems, 50: 41-52.

Altunal, M. (1998). Karayolları Ağaçlandırma Çalışmalarının Kritiği. İstanbul Üniversitesi Fen Bilimleri Enstitüsü Peyzaj Mimarlığı Anabilim Dalı Yüksek Lisans Tezi, İstanbul.

Avşar, B. (1993). Tarsus-Pozantı Ayrımı-Adana-Gaziantep Otoyolu (Km 44+600-Km125+000) Arası Yapılan Peyzaj Planlama Çalışmaları Üzerine Bir Araştırma. Ç.Ü. Fen Bilimleri Enstitüsü Peyzaj Mimarlığı Anabilim Dalı, Yüksek Lisans Tezi, Adana.

Arslan, M., Barış, E., Erdoğan, E. ve Dilaver, Z. (2007). Yeşil Yol Planlaması Ankara Örneği. T.C. Ankara Üniversitesi Bilimsel Araştırma Projesi Kesin Raporu.

Bayraktar, A. (1980). Karayollarının Ekolojik Baskılarıın Peyzaj Mimarlığının Açısından İrdelenmesi ve İzmirAnkara Karayolunda Bir Örnekleme Üzerime Araştırmalar. Ege Üniversitesi Ziraat Fakültesi Yayınları No: 423, Ege Üniversitesi Matbaası, İzmir, 90s.

Brown, G. (2003). A Method For Assesing Highway Qualities to Integrate Values in Higway Planing. Journal of Transport Geography, 11(4), December 2003, pages 271-283.

Caf, A. (2014). Bingöl-Erzurum Karayolu Güzergâhının Görsel Kalite Analizi. Atatürk Üniversitesi Fen Bilimleri Enstitüsü, Yüksek Lisans Tezi, 106 s.

Clay, G.R. and Smidt, R.K. (2004). Assessing The Validity and Reliability of Descriptor Variables Used in Scenic Highway Analysis. Landscape and Urban Planning, 66(4): 239-255. 
Çil, E. (1995). Kent Girişi Karayolu Koridorunun Mekânsal Değerlendirmesine Yönelik Bir Araştırma. Yıldız Teknik Üniversitesi Fen Bilimleri Enstitüsü, F.B.E. Mimarlık Anabilim Dalı Mimari Tasarım Programı, Yüksek Lisans Tezi.

Çorbacı, Ö.L. ve Var, M. (2011). Bartın-Amasra Karayolunun Peyzaj Özelliklerinin Peyzaj Planlama Açısından İrdelenmesi vee Sorunların Giderilmesine Çeşitli Öneriler. Bartın Orman Fakültesi Dergisi, 13(20): 23-37.

Dağıstanlıoğlu, C. ve Önder, S. (2009). Isparta-Eğirdir Karayolunun Peyzaj Planlama ilkeleri Açısından İncelenmesi. Süleyman Demirel Üniversitesi Orman Fakültesi Dergisi, A(1): 154-166.

Denstadli, J.M. and Jacobsen, J.K.S. (2011). The Long and Winding Roads: Perceived Quality of Scenic Tourism Routes. Tourism Management, 32(4):780-789.

Eby, D.W. and Molnar, L.J. (2002). Importance of Scenic Byways in Route Choice: A Survey of Driving Tourists in The United States. Transportation Research Part A: Policy and Practice, 36(2): 95-106.

Ertaş, H. (1998). Bartın-İnkumu Karayolunun ve İnkumu'nun Peyzaj Değerleri Açısından İncelenmesi. Zonguldak Karaelmas Üniversitesi Fen Bilimleri Enstitüsü Peyzaj Mimarlı̆̆ı Anabilim Dalı, 156s.

Ertekin, M. ve Çorbacı, Ö.L. (2010). Karayollarında Peyzaj Planlama ve Bitkilendirme Çalışmaları. Ecological Life Sciences, 5(2): 106-125.

Fei, C.Y., Chuan, H., Shi-min, W. and Jin-long, Z. (2012). Landscape Design of Mountain Highway Tunnel Portals in China. Tunnelling and Underground Space Technology, 29: 52-68.

Güçlü, K. (1982). Trabzon-Erzurum Karayolunun Rekreasyon ve Turizm Yönünden Planlama ilkelerinin Saptanması, Atatürk Üniversitesi Ziraat Fakültesi, Doktora Tezi, Erzurum,1982.

Jaal, Z. and Abdullah, J. (2012.) User's Preferences of Highway Landscapes in Malaysia: A Review and Analysis of The Literature. Procedia -Social and Behavioral Sciences, 36: 265-272.

Jones, G.R., Ady, J. and Gray, B.A. (1976). Scenic and Recreational Highway Study for The State of Washington. Landscape Planning, 3(3): 151-302.

Karahan, F. ve Yılmaz, H. (2004). Erzurum-Rize Karayolu Koridorunun Görsel Kalite Analizi. TMMOB Peyzaj Mimarları Odası Peyzaj Mimarlığı II. Kongresi, 25-27 Kasım 2004, Ankara.

Kent, R. (1993). Determining Scenic Quality Along Highways: A Cognitive Approach. Landscape and Urban Planning, 27(1): 29-45.

Kent, R.L. and Elliott, C.L. (1995). Scenic Routes Linking and Protecting Natural and Cultural Landscape Features: A Greenway Skeleton. Lanscape and Urban Planning, 33(1-3): 341-355.

Kınıklı, P. ve Mansuroğlu, S. (2010). Antalya-Alanya Devlet Karayolundan Kaynaklanan (I. Kesim) Çevresel Etkilerin Peyzaj Mimarlığı Açısından Değerlendirilmesi. Akdeniz Üniversitesi Ziraat Fakültesi Dergisi, 23(1): 15-21.

Koç, N. (1979). Karayolları Ağaçlamasını İşlev ve Estetik Yararları, Teknik Yöntemleri. Peyzaj Mimarlığı Dergisi Karayolları Özel Sayısı, 1: 13-18.

Koçan, N. (2007). Gümüşhane-Trabzon Karayolu Güzergâhı Peyzaj Değerlerinin İrdelenmesi. Artvin Çoruh Üniversitesi Orman Fakültesi Dergisi, 8 (1): 37-45.

Lambe, R.A. and Smardon, R.C. (1986). Commercial Higway Landscape Reclamation: A Participatory Approach. Landscape and Planning, 12,(4): 353-385.

Özgünç, İ.M. (1999). TEM Hadımköy-Kınalı Arası Peyzaj Planlama Üzerine Görsel Araştırmalar. İstanbul Üniversitesi Fen Bilimleri Enstitüsü, Doktora Tezi, 228s.

Öztürk, B. (2002). Kent İçi ve Kent Dışı Karayolu Ulaşım Sisteminde Bitkilendirmenin Trafik Tekniği Yönünden İşlevleri. Gazi Üniversitesi Uluslar Arası Trafik ve Yol Güvenliği Kongresi, 8-12 Mayıs 2002, Ankara.

Saatçioğlu, F. (1960). En Önemli Silvikültürel ve Estetik Özellikleriyle Şehir Ve Yol Ağaçları. İstanbul Üniversitesi Orman Fakültesi Dergisi, B(10,2):1-24

Seçkin, Ö.B. (1985). Peyzaj Yolu Kavramı ve Dizayn Esasları. İstanbul Üniversitesi Orman Fakültesi Dergisi, B $(35,2): 70-81$.

Seçkin, B. (1986). Karayolu Ve Peyzajı. İstanbul Üniversitesi Orman Fakültesi Dergisi, B(36,4): 46-53.

Seçkin, Ö.B. (1997). Peyzaj Yapıları, II. İstanbul Orman Fak. Yay. No: 235s, İstanbul. 
Selimoğlu, B. (1994). Ülkemiz Otoyollarında Çevre, Düzenleme İlkelerinin Belirlenmesi Üzerine Bir Araştırma. Ankara Üniversitesi Fen Bilimleri Enstitüsü Peyzaj Mimarlığı Anabilim Dalı Doktora Tezi, Ankara.

Sezen, I. (2009). Erzurum-Bayburt-Of Karayolu Güzergâhının Manzara Yolu Olarak Değerlendirilmesine Yönelik Görsel Analiz. Atatürk Üniversitesi Fen Bilimleri Enstitüsü, Peyzaj Mimarlığı Anabilim Dalı Doktora Tezi, $184 \mathrm{~s}$.

Sezen, I. (2015). Environment and Ecology at The Beginning af 21st Century, Chapter: (Visual Quality Analysis For Roadside Landscape Scenes Of Erzurum-Erzincan (Turkey) Highway Route). St. Klıment Ohrıdskı University Presss.

Sezen, I. ve Yılmaz, S. (2010). Visual Assesment for The Eveluation of Erzurum-Bayburt-Of Highways as Scenic Road. Scientific Research and Essay 5(4), 366-377.

Sezen, I. and Yılmaz, S. (2017). Ekolojik Koridorların Turizme Katkısı: Erzurum-Bayburt-Of Karayolu Güzergâhı. DOKAP Bölgesi Uluslararası Turizm Sempozyumu Bildiriler Kitabı, 23-24 Ekim 2017, Karadeniz Teknik Üniversitesi, Trabzon, Türkiye.

Sosyaler, H. (1973). Yol Boylarında Erozyon Kontrolü Emniyet ve Estetik. Karayolları Genel Müdürlüğü Bakım Dairesi Başkanlığı Bakım Fen Heyeti Müdürlüğü, Ankara.

Tabrizi, A.R.M. (1988). Adana- İmamoğlu-Kozan Yeni Devlet Karayolunun Peyzaj Mimarlığı İlkeleri İçinde Değerlendirilmesi Üzerine Bir Araştırma. Çukurova Üniversitesi Fen Bilimleri Enstitüsü Peyzaj Mimarlığı Anabilim Dalı, Yüksek Lisans Tezi, 70s.

Tanrıverdi, F. (1975). Karayolları Ağaçlandırma Rehberi. Karayolları Genel Müdürlüğü Matbaası, Ankara.

Tunay, M., Yılmaz, B. ve Ateşoğlu, A. (2008). Bartın-Amasra Karayolu Güzergâhının Doğal Peyzaj Özellikleri Üzerindeki Etkilerinin Saptanması. Ekoloji, 17(66): 23-30.

Ürgenç, S.í. (2000). Kırsal Peyzaj. YTÜ. Mimarlık Fakültesi Şehir ve Bölge Planlama Bölümü. Sf.173-188. YTÜ. Basım yayın Merkezi, İstanbul.

Wu CF, Lin Y, Chiang L, Huang T (2014) Assessing highway's impacts on landscape patterns and ecosystem services: A case study in Puli Township, Taiwan. Landscape and Urban Planning, 128: 60-71

URL-1. (2017). https://www.travelandleisure.com/slideshows/americas-most-scenic-roads\#13

URL-2. (2017). https://www.vermontinn.com/innkeepers-blog/the-byways-of-vermont

URL-3. (2017). https://www.hemmings.com/magazine/hmn/2014/01/Highland-Scenic-Highway/3734291.html

URL-4. (2017). http://www.topangamalibuproperty.com/californias-scenic-highways-and-what-it-takes-topreserve-them/

URL-5. (2017). https://listekitap.com/gezi/dunyanin-en-muthis-manzaralarina-sahip-13-yol/

URL-6. (2017). https://www.dangerousroads.org/?start=189

URL-7. (2017). https://www.dangerousroads.org/component/search/?searchword=north\%20yungos\&search phrase $=$ all\&ltemid $=120$

URL-8. (2017). https://www.skyscanner.com.tr/haberler/tuerkiyenin-en-guezel-manzarali-7-suerues-rotasi 